The relationship between multiple intelligences and speaking skill among intermediate EFL learners in Bandar Abbas Azad University in Iran

Saibani, Bahare

Payame Noor University, Iran (Saibani.bahare@yahoo.com)

Simin, Shahla

University of Isfahan, Iran (shahlasimin@yahoo.com)

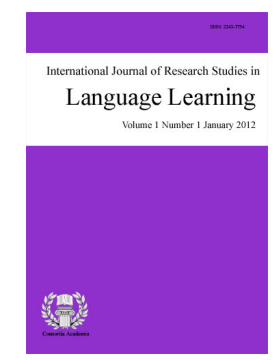

ISSN: 2243-7754 Online ISSN: 2243-7762

OPEN ACCESS

\title{
Abstract
}

This research aims at identifying the relationship between multiple intelligences (MI) and speaking ability among Iranian EFL learners as well as the effect of gender on the relationship. The participants in this study were EFL sophomores majoring in translation at Bandar Abbas Islamic Azad University in Iran. The findings of the study revealed that there is a significant relationship between MI and speaking ability. And according to the multiple regression analyses it was shown that linguistic-verbal (both in males and females), interpersonal (in males), and intrapersonal (in males) intelligences are the main predictors of speaking ability in this study. Furthermore, it is shown that there is no significant difference between speaking ability of males and females in the study.

Keywords: intelligence; multiple intelligences; speaking skill 


\section{The relationship between multiple intelligences and speaking skill among intermediate EFL learners in Bandar Abbas Azad University in Iran}

\section{Introduction}

The ability to speak in a foreign language, as noted by Luoma (2004), is at the very heart of what it means to be able to use a foreign language. Unfortunately, speaking English is a skill that has been improved less than other skills of language learning in Iran. Unlike reading and writing, speaking cannot be done in solitude and requires the presence of an addressee or audience. This may have its psychological barriers. For example, learners are often inhibited about making mistakes, fearful of criticism or losing face, or simply shy of the attention that their speech attracts (Ur, 1996). The researchers think that these problems can be related to some dimensions of multiple intelligences. The next point is that it may not always be possible to find ways to include all of the intelligences into lesson plans and tests. However, if the teacher is able to incorporate more variances and reach a few more intelligences than they otherwise would have, whilst allowing students to have a choice in the way they grasp different skills, it should make the students more successful.

The main objective of the current study is to investigate whether speaking ability has any significant correlation with any type or types of multiple intelligences. The second objective deals with whether any intelligence or combination of intelligences can predict the strengths or weaknesses in Iranian EFL learners' speaking ability. And finally, the third objective is to find if gender makes any difference in the relationship between multiple intelligences and speaking ability among Iranian EFL learners.

This research will answer the following questions:

1. Is there any relationship between multiple intelligences and speaking ability among Iranian EFL learners?

2. Can intelligence or combination of intelligences predict the strengths or weaknesses in Iranian EFL learners' speaking ability?

3. Does gender make any difference in the relationship between multiple intelligences and speaking ability among Iranian EFL learners?

To examine the above research questions, the following corresponding hypotheses were formulated:

H1. There is a relationship between multiple intelligences and speaking ability among Iranian EFL learners.

H2. Intelligence or combination of intelligences can predict the strengths or weaknesses in Iranian EFL learners' speaking ability.

H3. Gender has an effect on the relationship between multiple intelligences and speaking ability among Iranian EFL learners.

Multiple intelligences model has provided us with the opportunity to look differently at curriculum, instruction, and assessment. Moreover, any indication of the relationship between each part of multiple intelligences and speaking skill can help teachers as well as those who are involved in this process. Based on this study, it is hoped that teachers become more aware of differences among students. Thus, teachers must take these differences into account and the skills should be taught in different ways. In fact, teaching skills in a variety of ways enables students to make the most of their intellectual strengths and even to work toward correcting or at least compensating for their weaknesses and thus improve learning process. 


\section{Review of the Related Literature}

As stated by (Gottfredson 1997),

"Intelligence is a very general mental capability that among other things involves the ability to reason, plan, solve problems, think abstractly, comprehend complete ideas, learn quickly and learn from experience" (p .13).

In this connection, Spearman (1927) claimed that there is a relationship between intelligence and a variety of intellectual performance. He believed that people who perform well on intelligence tests also perform well on other intellectual tasks, such as vocabulary, mathematical, and spatial abilities.

Traditional views of intelligence base human intellect on the results of paper and pencil tests and statistical analysis. If a test is reasonably challenging, some students score better and some worse. Those who perform better than most are said to have a higher amount of something called "intellect", as expressed in a number or "quotient" - hence the term Intelligence Quotient, or IQ. So this type of intelligence was accepted for all. According to Geary (2005), IQ is highly correlated with many important social outcomes. Individuals with low IQs are more likely to be divorced, and more likely to have a child out of marriage, more likely to be incarcerated, and more likely to need long term welfare support. Furthermore, he found that high IQs are associated with more years of education, higher status jobs, and higher income.

A number of critics have challenged the relevance of psychometric intelligence in the concept of everyday life. They believe that IQ tests do not measure creativity, character, personality, or other important differences among individuals (Gottfredson, 1997. The American psychologist, Howard Gardner, professor of education of Harvard University, put forth a new and different view of human intellectual competence 'Multiple Intelligence Theory' in 1983, as presented in his book 'Frames of Mind' (Gardner, 1983). Gardner and Hatch (1989) viewed "intelligence as the ability to solve problems or to create fashion products that are valued in one's own culture or society" (pp.4-9). This definition challenged the traditional psychological view of intelligence as a single capacity that drives ways that in combinations enable people to understand, perceive the word, and to express themselves (Gardner, 1983).

According to Gardner (1983), all human being possess all different intelligences in varying amounts and each individual manifests varying levels of these different intelligences and thus each person has a unique cognitive profile. Multiple intelligences consist of three domains. These three domains serve as an organizer for understanding the fluid relationship of intelligences and how the intelligences work together; teachers can plan lessons and units which effectively address all of the intelligences in the classroom (Mckenzie, 2002). The domains are shown in Figure 1.

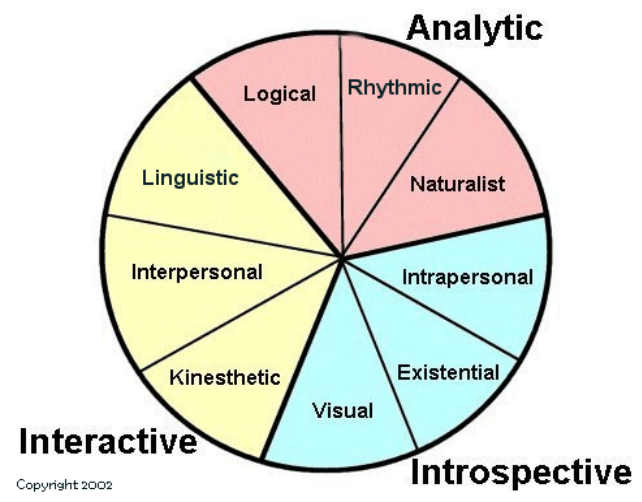

Figure 1. Multiple Intelligence Domains (Mckenzie, 2002)

Logical, rhythmic, and naturalist intelligences are considered analytic because, they promote the process of analyzing and incorporating data into existing schema, even though they may have other components (Mckenzie, 
2002). Linguistic, interpersonal, and kinesthetic intelligences are regarded interactive because, they typically invite and encourage interaction to achieve understanding, even if a student completes a task individually, s/he must consider others through the way s/he writes, creates, constructs, and makes conclusion (Mckenzie, 2002).

Intrapersonal, existential, and visual intelligences are characterized introspective because they require a looking inward by the learner, an emotive connection to their own experiences and beliefs in order to make sense of new learning (Mckenzie, 2002). Gardner (1983) suggested that individuals have personal intelligence profile that consists of combinations of seven different intelligence types. In 1997, Gardner added an 8th intelligence type to the list, that is natural intelligence, and 2 years later a 9th type, existential intelligence. He claimed that different intelligences rarely operate independently; they are used at the same time and tend to complete each other. Though he doesn't believe the list is necessarily complete (Gardner, 1999, p.41-43).

Gardner $(1983,1999)$ has described the intelligences in this way:

Linguistic intelligence: the ability to use words and language, and sensitivity to meaning and order of words. Moreover, it is the capacity to use language to express one's ideas and opinions, and to accomplish certain goals as well as the ability to master foreign language.

Logical/ mathematical intelligence: the ability to think and to analyze problems logically, to carry out mathematical operations analytically, and to conduct scientific investigations as well as to understand logical patterns, categories, cause and effect relationships in the world and to use inductive and deductive reasoning.

Visual intelligence: the ability to think in images or pictures and visualize objects from different dimensions. People with high visual intelligence picture ideas and solutions to problems in their mind.

Musical intelligence: the ability to recognize tones, rhythms and musical patterns also, the capacity to understand and express oneself musically.

Bodily/Kinesthetic intelligence: the capacity to use your whole body or parts of your body: your hands, your fingers, your arms, to solve a problem, make something, or put on some kind of production.

Naturalist intelligence: the ability to, and interest in, identifying the natural things around us, such as birds, flowers, animals, and trees. It also entails sensitivity to nature, the ecology, and geological features of our world.

Intrapersonal intelligence: having an understanding of yourself, of knowing who you are, what you can do, what you want to do, how you react to things, which things to avoid, and which things to gravitate toward.

Interpersonal intelligence: the ability to understand other people; an ability we all need. Anybody who deals with other people has to be skilled in the interpersonal sphere.

Existential intelligence: exhibition of the proclivity to pose (and ponder) questions about life, death, and ultimate realities. Existential intelligence is considered as the intelligence of understanding in a larger context or big picture.

In Gardner's view, learning is both a social and psychological processes. Beliefs about intelligence shape the very way that schools and classes are structured, classroom created with the belief that each person possesses at least intelligences to understand, perceive the world and express them. These intelligences all function together in different ways that are unique to each person.

In this respect, Lakshmi (2007) investigated the impact of Multiple Intelligences (MI) research conducted in a Primary School Tamil Class and its role in developing the standard of students' Spoken Tamil. The class comprised of students from Tamil and non-Tamil speaking homes enjoyed the lessons and developed their speaking skills through the effort. His aim was to explore the use of the Multiple Intelligences approach to develop Standard Spoken Tamil (SST) amongst primary school students. Many of the students mentioned that 
The relationship between multiple intelligences and speaking skill among intermediate EFL learners in Iran

they have gained benefits through this Multiple Intelligences approach in Tamil lessons.

In sum, the literature related to intelligence in general and MI in particular indicates that the so-called one-size-fits-all IQ tests were traditionally perceived to be true representations of students' intelligence. However, as Gottfredson (1997) notes, this view attracted heavy criticism, which in turn gave birth to a new and different view of human intellectual competence (Gardner, 1983; Gardner \& Hatch,1989). Gardner (1983) points out that individuals enjoy varying levels of different intelligences, giving weight to the view that each person has a unique cognitive profile. Gardner (1999) further developed intelligences into three separate but related categories, namely, analytic, interactive, and introspective, each comprising some abilities. Regarding our particular concern, language learning, ever since a good deal of research has been conducted investigating the role of MI in foreign language performance (e.g. Lakshmi, 2007). Nonetheless, given that Gardner's model of multiple intelligences is largely a theory and is not rooted in hard evidence, its impact on language learning may always be open to question. With this in mind, the present study can shed new light on this area of research. Furthermore, because of the fact that the impact of MI on the development of speaking skills of Iranian EFL learners remains uninvestigated, this study makes an effort to lay a sound basis for decision makers, curriculum designers, language teachers, researchers, and others involved in the field of English language teaching and learning.

\section{Methodology}

The participants of this study were EFL sophomores majoring in translation. They were selected among EFL learners in Bandar Abbas Azad University based on cluster sampling. All participants had passed listening and speaking course I, II, and III. After the scores of interview were obtained those students whose scores were within 1 Standard Deviation (SDs) minus and 1 plus the mean were selected and the rest were excluded. The final test takers were 60 students. The participants consisted of 30 males and 30 females. They were from different cities and towns in Hormozgan province. This study was done on intermediate students. The instruments employed were:

$>\quad$ An evaluation sheet to assess the speaking ability of the participants. This evaluation sheet was prepared according to Kent (2001). It took about 10 to 20 minutes for each learner to be interviewed.

$>$ A multiple intelligence questionnaire based on Gardner's nine dimensions to determine the participants' preferred intelligences. This questionnaire is a combination of two MI tests, including: Nail's (2002) MI test of Ned Production and MI inventory (Mckenzie, 1999). It took about 25 minutes on average to complete 90 multiple-choice and there was no time limit.

For validity and reliability indexes, the original English version was translated into Persian then it was translated back into English by several experts. The reliability of the test was calculated using Cronbach alpha. The index of reliability (above 0.90 ) indicates that the test is highly reliable. The reliability of this standardized test was measured by Nail's (2002). To ascertain the construct validity of the items and to determine the underlying variables (i.e. factors) that account for the correlations among observed variables principle factor analysis was used. The results of factor analysis demonstrate that there are 9 factors or constructs or in other words, 9 segments of intelligence.

In the first session, for having a homogeneous group, the participants were interviewed. In the second session, the Likert Scale MI questionnaire, measuring 9 domains of participants' intelligence was used (there was no time limit). In the third and the fourth sessions the participants were also assessed on their speaking ability through oral interview. The researcher and the second rater assessed them based on their pronunciation, grammar use, vocabulary appropriateness and complexity, fluency of speech and listening comprehension in English. In each part the learners got a score from 1 to 4 , so a total score of 5 to 20 was the possible score for the speaking ability. 


\section{Results}

In order to test the research hypotheses a number of descriptive and inferential analyses were conducted on the data. At first, descriptive statistics of different types of intelligences of male and female participants are shown. The results appear in Table 1 . Then, descriptive statistics of speaking ability components for males and females are demonstrated. The statistics are presented in Table 2. Then, correlations between different types of multiple intelligences and speaking ability components are shown in Table 3. Furthermore, regression analysis was performed for the calculation of linear model between speaking ability and different types of multiple intelligences. The analyses are presented in Table 4. Finally, for prediction of speaking ability by different types of multiple intelligences, multiple regressions were carried out which can be seen in Tables 5 and 6 . As shown in Table 1, the mean of scores for different types of multiple intelligences was higher for male participants than females.

\section{Table 1}

Descriptive statistics of different types of multiple intelligences of males and females

\begin{tabular}{llllcc}
\hline \multicolumn{1}{c}{ Intelligence Types } & Gender & $\mathrm{N}$ & Mean & SD & Variance \\
\hline \multirow{2}{*}{ linguistic-verbal } & Male & 30 & 5.8000 & 2.13993 & 4.579 \\
\cline { 2 - 6 } & Female & 30 & 5.7000 & 2.45160 & 6.010 \\
\hline \multirow{2}{*}{ visual-spatial } & Male & 30 & 5.6667 & 1.49328 & 2.230 \\
\cline { 2 - 6 } & Female & 30 & 5.3667 & 1.75152 & 3.068 \\
\hline \multirow{2}{*}{ musical-rhythmic } & Male & 30 & 5.9000 & 1.56139 & 2.438 \\
\cline { 2 - 6 } & Female & 30 & 5.8000 & 1.66919 & 2.786 \\
\hline bodily-kinesthetic & Male & 30 & 5.3000 & 1.89646 & 3.597 \\
\cline { 2 - 6 } & Female & 30 & 5.2667 & 1.98152 & 3.926 \\
\hline naturalist & Male & 30 & 5.7333 & 1.68018 & 2.823 \\
\cline { 2 - 6 } & Female & 30 & 5.3667 & 1.73172 & 2.999 \\
\hline intrapersonal & Male & 30 & 5.4000 & 1.58875 & 2.524 \\
\cline { 2 - 6 } & Female & 30 & 4.9333 & 1.79911 & 3.237 \\
\hline interpersonal & Male & 30 & 5.8000 & 1.47157 & 2.166 \\
\cline { 2 - 6 } & Female & 30 & 5.6333 & 1.71169 & 2.930 \\
\hline existential & Male & 30 & 5.8333 & 1.41624 & 2.006 \\
\cline { 2 - 6 } & Female & 30 & 5.3667 & 1.44993 & 2.102 \\
\hline multiple intelligences & Male & 30 & 5.3000 & 1.74494 & 3.045 \\
\cline { 2 - 6 } & Female & 30 & 4.9667 & 1.69143 & 2.861 \\
\hline & Male & 30 & 50.7333 & 5.73515 & 32.892 \\
\cline { 2 - 6 } & Female & 30 & 48.4000 & 6.51047 & 42.386 \\
\hline
\end{tabular}

Table 2

Descriptive statistics of speaking ability and its components for males and females

\begin{tabular}{|c|c|c|c|c|c|}
\hline Test Types & Gender & $\mathrm{N}$ & Mean & SD & Variance \\
\hline \multirow[t]{2}{*}{ fluency of speech } & Male & 30 & 16.7667 & 3.75714 & 14.116 \\
\hline & Female & 30 & 16.0333 & 4.12297 & 16.999 \\
\hline \multirow[t]{2}{*}{ grammar use } & Male & 30 & 16.0667 & 4.33855 & 18.823 \\
\hline & Female & 30 & 16.5333 & 3.72071 & 13.844 \\
\hline \multirow[t]{2}{*}{ listening comprehension } & Male & 30 & 16.5333 & 4.10830 & 16.878 \\
\hline & Female & 30 & 16.4333 & 4.67335 & 21.840 \\
\hline \multirow[t]{2}{*}{ pronunciation } & Male & 30 & 16.0333 & 4.32701 & 18.723 \\
\hline & Female & 30 & 16.3000 & 4.70620 & 22.148 \\
\hline \multirow[t]{2}{*}{ vocabulary appropriateness and complexity } & Male & 30 & 15.3333 & 4.80182 & 23.057 \\
\hline & Female & 30 & 16.7931 & 5.04536 & 25.456 \\
\hline \multirow[t]{2}{*}{ speaking Ability } & Male & 30 & 80.7333 & 17.94615 & 322.064 \\
\hline & Female & 30 & 81.5333 & 18.94590 & 358.947 \\
\hline
\end{tabular}

Although the total score of speaking ability was higher in females than males, Table 2 shows that there was 
The relationship between multiple intelligences and speaking skill among intermediate EFL learners in Iran no significant difference between speaking ability of males and females in the study.

As Table 3 shows, linguistic-verbal intelligence has significant correlations with speaking ability and all of its components in male and female participants $(p<0.01)$. In addition, intrapersonal intelligence had significant correlations with speaking ability and all of its components in males. Furthermore, interpersonal intelligence had correlations with speaking ability and three of its components which are fluency of speech, grammar use, vocabulary appropriateness and complexity in males.

\section{Table 3}

Correlations between different types of multiple intelligences and speaking ability and its components

\begin{tabular}{|c|c|c|c|c|c|c|c|c|}
\hline Intelligence Types & Correlation & Gender & $\begin{array}{l}\text { fluency } \\
\text { of speech }\end{array}$ & $\begin{array}{l}\text { Grammar } \\
\text { use }\end{array}$ & $\begin{array}{c}\text { listening } \\
\text { comprehension }\end{array}$ & $\begin{array}{l}\text { Pronun- } \\
\text { ciation }\end{array}$ & $\begin{array}{l}\text { Vocabulary } \\
\text { appropriateness \& } \\
\text { complexity }\end{array}$ & $\begin{array}{l}\text { speaking } \\
\text { ability }\end{array}$ \\
\hline \multirow[t]{2}{*}{ linguistic-verbal } & \multirow{2}{*}{$\begin{array}{l}\text { Pearson } \\
\text { Correlation }\end{array}$} & Male & $.753^{* *}$ & $.767^{* *}$ & $.597^{* *}$ & $.690^{* *}$ & $.631^{* *}$ & $.815^{* *}$ \\
\hline & & Female & $.745^{* *}$ & $.718^{* *}$ & $.743^{* *}$ & $.767^{\text {** }}$ & $.717^{* *}$ & $.817^{* *}$ \\
\hline \multirow{2}{*}{$\begin{array}{l}\text { logical- } \\
\text { mathematical }\end{array}$} & \multirow{2}{*}{$\begin{array}{l}\text { Pearson } \\
\text { Correlation }\end{array}$} & Male & .115 & .073 & .114 & .093 & -.123 & .057 \\
\hline & & Female & -.255 & -.068 & .026 & -.110 & -.283 & -.191 \\
\hline \multirow[t]{2}{*}{ visual-spatial } & \multirow{2}{*}{$\begin{array}{l}\text { Pearson } \\
\text { Correlation }\end{array}$} & Male & -.445 & -.432 & -.244 & -.367 & $-.584^{* *}$ & $-.498^{* *}$ \\
\hline & & Female & -.405 & -.299 & -.320 & -.356 & -.460 & -.456 \\
\hline \multirow[t]{2}{*}{ musical-rhythmic } & \multirow{2}{*}{$\begin{array}{l}\text { Pearson } \\
\text { Correlation }\end{array}$} & Male & -.135 & -.283 & .045 & -.127 & -.133 & -.153 \\
\hline & & Female & -.453 & -.394 & -.434 & -.401 & -.351 & -.454 \\
\hline \multirow[t]{2}{*}{ bodily-kinesthetic } & \multirow{2}{*}{$\begin{array}{l}\text { Pearson } \\
\text { Correlation }\end{array}$} & Male & -.458 & -.409 & -.458 & -.430 & -.450 & $-.524^{* *}$ \\
\hline & & Female & -.451 & -.401 & -.357 & -.407 & -.234 & -.402 \\
\hline \multirow[t]{2}{*}{ naturalist } & \multirow{2}{*}{$\begin{array}{l}\text { Pearson } \\
\text { Correlation }\end{array}$} & Male & -.382 & -.234 & -.182 & -.132 & -.104 & -.238 \\
\hline & & Female & -.437 & -.278 & .024 & -.197 & -.183 & -.225 \\
\hline \multirow[t]{2}{*}{ intrapersonal } & \multirow{2}{*}{$\begin{array}{l}\text { Pearson } \\
\text { Correlation }\end{array}$} & Male & $.528^{* * *}$ & $.575^{\text {** }}$ & $.572^{* *}$ & $.521^{* * *}$ & $.590^{* *}$ & $.664^{* * *}$ \\
\hline & & Female & .280 & .373 & .275 & .164 & .349 & .327 \\
\hline \multirow[t]{2}{*}{ interpersonal } & \multirow{2}{*}{$\begin{array}{l}\text { Pearson } \\
\text { Correlation }\end{array}$} & Male & $.524^{* *}$ & $.485^{* *}$ & .194 & .310 & $.551^{* *}$ & $.493^{* *}$ \\
\hline & & Female & .113 & .167 & .286 & .140 & .251 & .215 \\
\hline \multirow[t]{2}{*}{ existential } & \multirow{2}{*}{$\begin{array}{l}\text { Pearson } \\
\text { Correlation }\end{array}$} & Male & $-.578^{* *}$ & -.358 & -.143 & -.248 & -.239 & -.364 \\
\hline & & Female & -.366 & -.463 & -.286 & -.038 & -.256 & -.318 \\
\hline \multirow{2}{*}{$\begin{array}{l}\text { multiple } \\
\text { intelligence }\end{array}$} & \multirow{2}{*}{$\begin{array}{l}\text { Pearson } \\
\text { Correlation }\end{array}$} & Male & -.006 & .067 & .167 & .112 & .055 & .095 \\
\hline & & Female & -.266 & -.113 & .046 & -.052 & -.068 & -.116 \\
\hline
\end{tabular}

Note. $* *$ Correlation is significant at the 0.01 level (2-tailed)

Table 4 shows that only component of fluency of speech has significant linear relation with all types of multiple intelligences, of course there are some significant linear relations between other components of speaking ability and different types of multiple intelligences. Furthermore, none of speaking ability components had significant linear relation with total score of multiple intelligences.

\section{Table 4}

Regression analysis of speaking ability and its components with different types of multiple intelligences

\begin{tabular}{|c|c|c|c|c|c|c|c|}
\hline \multirow{2}{*}{$\begin{array}{l}\text { Dependent } \\
\text { Variables }\end{array}$} & \multirow[t]{2}{*}{ Predictor Variables } & \multicolumn{2}{|c|}{ MS } & \multirow[t]{2}{*}{$\mathrm{F}$} & \multirow[t]{2}{*}{$\mathrm{R}$} & \multirow[t]{2}{*}{ R Square } & \multirow{2}{*}{$\begin{array}{l}\text { Std. Error of the } \\
\text { Estimate }\end{array}$} \\
\hline & & Regression & Residual & & & & \\
\hline \multirow[t]{10}{*}{ fluency of speech } & linguistic-verbal & 507.811 & 6.941 & $73.159^{* *}$ & .747 & .558 & 2.63461 \\
\hline & logical-mathematical & 6.362 & 15.587 & .408 & .084 & .007 & 3.94802 \\
\hline & visual-spatial & 159.243 & 12.951 & $12.296 * *$ & .418 & .175 & 3.59875 \\
\hline & musical-rhythmic & 83.283 & 14.261 & 5.840 & .302 & .091 & 3.77633 \\
\hline & bodily-kinesthetic & 175.582 & 12.669 & $13.859 * *$ & .439 & .193 & 3.55939 \\
\hline & naturalist & 141.047 & 13.265 & $10.633 * *$ & .394 & .155 & 3.64207 \\
\hline & intrapersonal & 139.546 & 13.291 & $10.500 * *$ & .376 & .141 & 3.67501 \\
\hline & interpersonal & 91.106 & 14.126 & 6.450 & .316 & .100 & 3.75843 \\
\hline & existential & 187.772 & 12.459 & $15.071 * *$ & .454 & .206 & 3.52975 \\
\hline & multiple intelligence & 15.210 & 15.434 & .985 & .129 & .017 & 3.92865 \\
\hline \multirow[t]{10}{*}{ grammar } & linguistic-verbal & 509.098 & 7.612 & $66.880 * *$ & .732 & .536 & 2.75901 \\
\hline & logical-mathematical & .011 & 16.389 & .001 & .003 & .000 & 4.04839 \\
\hline & visual-spatial & 127.956 & 14.184 & $9.021 * *$ & .367 & .135 & 3.76610 \\
\hline & musical-rhythmic & 106.032 & 14.562 & $7.282 * *$ & .334 & .112 & 3.81596 \\
\hline & bodily-kinesthetic & 157.233 & 13.679 & $11.495 * *$ & .407 & .165 & 3.69848 \\
\hline & naturalist & 63.499 & 15.295 & 4.152 & .258 & .067 & 3.91086 \\
\hline & intrapersonal & 204.549 & 12.863 & $15.902 * *$ & .464 & .215 & 3.58649 \\
\hline & interpersonal & 97.424 & 14.710 & 6.623 & .320 & .102 & 3.83535 \\
\hline & existential & 158.195 & 13.662 & $11.579 * *$ & .408 & .166 & 3.69624 \\
\hline & multiple intelligence & .984 & 16.373 & .060 & .032 & .001 & 4.04632 \\
\hline
\end{tabular}


Saibani, B. \& Simin, S.

Table 4 ... continue

Regression analysis of speaking ability and its components with different types of multiple intelligences

\begin{tabular}{|c|c|c|c|c|c|c|c|}
\hline \multirow{2}{*}{$\begin{array}{l}\text { Dependent } \\
\text { Variables }\end{array}$} & \multirow[t]{2}{*}{ Predictor Variables } & \multicolumn{2}{|c|}{ MS } & \multirow[t]{2}{*}{$\mathrm{F}$} & \multirow[t]{2}{*}{$\mathrm{R}$} & \multirow[t]{2}{*}{ R Square } & \multirow{2}{*}{$\begin{array}{c}\text { Std. Error of the } \\
\text { Estimate }\end{array}$} \\
\hline & & Regression & Residual & & & & \\
\hline \multirow{10}{*}{$\begin{array}{l}\text { listening } \\
\text { comprehension }\end{array}$} & linguistic-verbal & 518.798 & 10.417 & $49.803 * *$ & .680 & .462 & 3.22754 \\
\hline & logical-mathematical & 4.710 & 19.281 & .244 & .065 & .004 & 4.39097 \\
\hline & visual-spatial & 91.273 & 17.788 & 5.131 & .285 & .081 & 4.21760 \\
\hline & musical-rhythmic & 51.709 & 18.470 & 2.800 & .215 & .046 & 4.29770 \\
\hline & bodily-kinesthetic & 179.148 & 16.273 & $11.009 * *$ & .399 & .160 & 4.03398 \\
\hline & naturalist & 4.548 & 19.283 & .236 & .064 & .004 & 4.39128 \\
\hline & intrapersonal & 181.985 & 16.224 & $11.217 * *$ & .403 & .162 & 4.02792 \\
\hline & interpersonal & 65.590 & 18.231 & 3.598 & .242 & .058 & 4.26977 \\
\hline & existential & 52.041 & 18.465 & 2.818 & .215 & .046 & 4.29704 \\
\hline & multiple intelligence & 11.102 & 19.170 & .579 & .099 & .010 & 4.37840 \\
\hline \multirow[t]{10}{*}{ pronunciation } & linguistic-verbal & 634.409 & 9.516 & $66.668 * *$ & .731 & .535 & 3.08479 \\
\hline & logical-mathematical & .667 & 20.443 & .033 & .024 & .001 & 4.52134 \\
\hline & visual-spatial & 155.373 & 17.775 & $8.741 * *$ & .362 & .131 & 4.21606 \\
\hline & musical-rhythmic & 88.342 & 18.931 & 4.667 & .273 & .074 & 4.35096 \\
\hline & bodily-kinesthetic & 207.973 & 16.868 & $12.329 * *$ & .419 & .175 & 4.10710 \\
\hline & naturalist & 34.508 & 19.859 & 1.738 & .171 & .029 & 4.45635 \\
\hline & intrapersonal & 120.873 & 18.370 & 6.580 & .319 & .102 & 4.28602 \\
\hline & interpersonal & 53.603 & 19.530 & 2.745 & .213 & .045 & 4.41926 \\
\hline & existential & 23.933 & 20.041 & 1.194 & .142 & .020 & 4.47676 \\
\hline & multiple intelligence & .261 & 20.450 & .013 & .015 & .000 & 4.52211 \\
\hline \multirow{10}{*}{$\begin{array}{l}\text { vocabulary } \\
\text { appropriateness } \\
\text { and complexity }\end{array}$} & linguistic-verbal & 617.559 & 13.952 & $44.262 * *$ & .661 & .437 & 3.73530 \\
\hline & logical-mathematical & 70.097 & 23.557 & 2.976 & .223 & .050 & 4.85356 \\
\hline & visual-spatial & 381.598 & 18.092 & $21.092 * *$ & .520 & .270 & 4.25348 \\
\hline & Musical-rhythmic & 82.830 & 23.334 & 3.550 & .242 & .059 & 4.83049 \\
\hline & bodily-kinesthetic & 171.061 & 21.786 & $7.852 * *$ & .348 & .121 & 4.66752 \\
\hline & naturalist & 37.465 & 24.130 & 1.553 & .163 & .027 & 4.91218 \\
\hline & intrapersonal & 277.876 & 19.912 & $13.955^{* *}$ & .443 & .197 & 4.46226 \\
\hline & interpersonal & 184.609 & 21.548 & $8.567 * *$ & .361 & .131 & 4.64199 \\
\hline & existential & 93.875 & 23.140 & 4.057 & .258 & .066 & 4.81039 \\
\hline & multiple intelligence & 2.332 & 24.746 & .094 & .041 & .002 & 4.97452 \\
\hline \multirow[t]{10}{*}{ speaking Ability } & linguistic-verbal & 13110.005 & 114.637 & $114.361 * *$ & .815 & .663 & 10.70685 \\
\hline & logical-mathematical & 132.189 & 338.392 & .391 & .082 & .007 & 18.39544 \\
\hline & visual-spatial & 4475.084 & 263.515 & $16.982 * *$ & .476 & .226 & 16.23313 \\
\hline & musical-rhythmic & 1908.345 & 307.769 & 6.201 & .311 & .097 & 17.54334 \\
\hline & bodily-kinesthetic & 4183.208 & 268.547 & $15.577 * *$ & .460 & .212 & 16.38740 \\
\hline & naturalist & 1057.097 & 322.445 & 3.278 & .231 & .053 & 17.95677 \\
\hline & intrapersonal & 4474.391 & 263.527 & $16.979 * *$ & .476 & .226 & 16.23350 \\
\hline & interpersonal & 2288.012 & 301.223 & $7.596 * *$ & .340 & .116 & 17.35577 \\
\hline & existential & 2295.590 & 301.092 & $7.624 * *$ & .341 & .116 & 17.35201 \\
\hline & multiple intelligence & 11.521 & 340.473 & .034 & .024 & .001 & 18.45190 \\
\hline
\end{tabular}

Table 5 shows that there are significant linear relation between given variables and total score of speaking ability. These variables are linguistic-verbal intelligence, interpersonal intelligence and intrapersonal intelligence.

Table 5

Regression Analysis for existence of linear relation

\begin{tabular}{|c|c|c|c|c|c|c|}
\hline & Model & Sum of Squares & df & Mean Square & $\mathrm{F}$ & Sig. \\
\hline \multirow[t]{3}{*}{1} & Regression & 13110.005 & 1 & 13110.005 & 114.361 & $.000^{\mathrm{a}}$ \\
\hline & Residual & 6648.928 & 58 & 114.637 & & \\
\hline & Total & 19758.933 & 59 & & & \\
\hline \multirow[t]{3}{*}{2} & Regression & 13594.370 & 2 & 6797.185 & 62.849 & $.000^{\mathrm{b}}$ \\
\hline & Residual & 6164.564 & 57 & 108.150 & & \\
\hline & Total & 19758.933 & 59 & & & \\
\hline \multirow[t]{3}{*}{3} & Regression & 14039.747 & 3 & 4679.916 & 45.824 & $.000^{\mathrm{c}}$ \\
\hline & Residual & 5719.186 & 56 & 102.128 & & \\
\hline & Total & 19758.933 & 59 & & & \\
\hline
\end{tabular}


In addition, Table 6 shows the components of linear relation for given variables for documentation of linear relation formula.

Table 6

Regression Analysis for determination of linear relation components

\begin{tabular}{lllllll}
\hline \multirow{2}{*}{ Model } & \multicolumn{2}{l}{ Unstandardized Coefficients } & \multicolumn{2}{l}{$\begin{array}{l}\text { Standardized } \\
\text { Coefficients }\end{array}$} & \multirow{2}{*}{$\mathrm{t}$} & Sig. \\
\cline { 3 - 5 } & & $\mathrm{B}$ & Std. Error & Beta & & \\
\hline \multirow{2}{*}{1} & (Constant) & 43.574 & 3.774 & & 11.544 & .000 \\
& linguistic-verbal & 6.532 & .611 & .815 & 10.694 & .000 \\
\hline 2 & (Constant) & 58.264 & 7.850 & & 7.422 & .000 \\
& linguistic-verbal & 5.970 & .650 & .744 & 9.183 & .000 \\
& interpersonal & -1.958 & .925 & -.172 & -2.116 & .039 \\
\hline 3 & (Constant) & 51.187 & 8.347 & & 6.132 & .000 \\
& linguistic-verbal & 5.379 & .692 & .671 & 7.772 & .000 \\
& interpersonal & -2.042 & .900 & -.179 & -2.269 & .027 \\
& intrapersonal & 1.917 & .918 & .166 & 2.088 & .041 \\
\hline
\end{tabular}

Given the results of Table 6 the linear relation formula is as follows:

Speaking Ability $=51.187+(5.379 *$ Linguistic-Verbal $)-(2.042 *$ Interpersonal $)+(1.917 *$ Intrapersonal $)$.

\section{Discussion and Conclusion}

There is probably no aspect of contemporary psychology that is more misunderstood by the general public than intelligence. The general public seems to have adopted the theory that intelligence is what an intelligence tests measures (Kail \& Pellegrina, 1985). There is also confusion within psychology. It reminds us of a wonderful book titled The Education of Little Tree (Carter, 1991), which deals with the difference between the skills that are considered intelligence and valued in the Native American Indian culture and the culture of the "white man" in the United States. In this connection, Gardner's MI theory proposes an alternative definition of intelligence based on a radically different view of the mind.

A number of studies attempted to show the positive consequences of applying multiple intelligence theory in education (Armstrong, 2002; Li, 2004; Armstrong, 2006; Hayat Gheibi, 2006; Sit, 2007; Saricaoglu \& Arikan, 2009). Saricaoglu and Arikan (2009) studied the relation between multiple intelligences, foreign language success and some selected variables. The aim of their study was to investigate the relationship between students' gender and intelligence types, the relationship between particular intelligence types and students' success in grammar, listening and writing in English as a foreign language and the relationship between parental education and students' types of intelligences. Preparatory class students $(n=144)$ attending Erciyes University's School of Foreign Languages participated in the study and the data was collected through the Multiple Intelligences. Analysis of the data revealed no significant gender differences in the intelligence types held by the participants except for that between gender and linguistic intelligence which was positive. Negative but significant relationships were found between success in students' test scores in grammar and bodily-kinesthetic, spatial, and intrapersonal intelligences whereas the relationship between musical intelligence and writing was found to be significant and positive. Finally, no significant relationship was found between parental education and students' intelligence types. In fact, the largest proportion of multiple intelligences investigations directly or indirectly concluded that multiple intelligences had significant relationship with learning language skills.

The findings of this study support the Gardner's multiple intelligence theory. In this research, factors such as gender, level of education, place of living, and place of study of the participants were taken into consideration. This study supports a considerable number of studies, conducted mostly after the 1990s, which showed evidence of support for the relationship between multiple intelligences and learning language skills. 
On the basis of findings of this study, it can be claimed that dimensions of multiple intelligences have significant relationships with language skills components. In fact, the findings of the study emphasized the point that teachers at all stages of education need to reflect on their practices and beliefs about multiple intelligences in order to optimize opportunities for learners to utilize and develop these intelligences.

Multiple regression showed that linguistic-verbal, interpersonal, and intrapersonal intelligences are the main predictors of speaking ability in this study; the predictor for women speaking skill was only linguistic intelligence; however, for men speaking skill the predictors were linguistic, interpersonal and intrapersonal intelligences. Also, there were some sporadic correlations between other types of multiple intelligence and speaking ability and its components. Moreover, it is shown that there is no significant difference between speaking ability of males and females in the study.

Furthermore, it is understood that specific opportunities for the development of multiple intelligences should be provided in early education settings. Integrating multiple intelligences into education represents a key component of students' success regardless of the presentation method. An instructor who gears course material to address the needs of multiple intelligences will encourage academic success and promote a quality learning experience.

Implications arising from this study suggest that language teachers, syllabus designers and material developers, as noted by Simin and Tavakoli (2014), should take into account this variation so as to meet different needs of students in order to optimize learning by considering and developing these intelligences in connection with speaking ability of learners. Since learners as individuals are unique, it is indisputable that we cannot assume that all are in favor of the specific strategy employed in the class (Maftoon \& Shakouri, 2012) and employ same type of intelligence. This issue is of paramount importance and need to be taken into consideration by language teachers, syllabus designers and material developers, in general, and Iranian EFL teachers, in particular.

\section{References}

Armstrong, T. (2002). The multiple intelligence of reading and writing: Making the words came alive.

Alexandria, VA: Association for Supervision and Curriculum Development.

Armstrong, T. (2006). Multiple intelligences in the classroom ( $2^{\text {nd }}$ ed.) [Arabic translation (H. Abdulghani,

Trans.). Al Khobar, Saudi Arabia: Educational Book House and Dhahran Ahliyya Schools.

Carter, F. (1991). The education of little tree. Albuquerque, NM: University of New Mexico Press.

Gardner, H. (1983). Frames of mind: The theory of multiple intelligences. New York: Basic Books.

Gardner, H. (1999). Intelligence reformed: Multiple intelligences for the $21^{\text {st }}$ century. New York: Basic Books.

Gardner, H., \& Hatch, T. (1989). Multiple intelligences go to schools: Educational implications of the theory of multiple intelligences. Educational Researcher, 18(8), 4-9.

Geary, D. C. (2005). The origin of mind: Evolution of brain, cognition, and general intelligence. Washington, DC: American Psychological Association.

Gottfredson, L. S. (1997). Main stream science on intelligence: An editorial with 52 signatories, history and bibliography. Intelligence, 24(1), 13-23. http://dx.doi.org/10.1016/S0160-2896(97)90011-8

Hayat Gheibi, M. (2006). A casual comparative study on multiple intelligences and listening comprehension in Iranian high school EFL learners. Unpublished masteral thesis, Islamic Azad University, Shiraz, Iran.

Kail, R., \& Pellegrina, J. (1985). Human intelligence: Perspectives and prospects. New York: W. H. Freeman and Company.

Kent, D. B. (2001). Exam evaluation criteria. The Internet TESL Journal, 7(6).

Lakshmi, S. (2007). Multiple intelligences approach in a Tamil classroom. Singapore Journal of Education, $31(2), 45-53$.

Li, L. (2002). Education for 1.3 billion: On 10 years of education reform and development. Beijing: Foreign Language Teaching and Research Press. 
The relationship between multiple intelligences and speaking skill among intermediate EFL learners in Iran

Luoma, S. (2004). Assessing Speaking. Cambridge: Cambridge University Press. http://dx.doi.org/10.1017/CBO9780511733017

Maftoon, P., \& Shakouri, N. (2012). Relationship between learners' beliefs system and the choice of language learning strategies: A critical study, 2(2), 39-48.

Mckenzie, W. (1999). MI survey. Retrieved May 2, 2010, Retrieved from http://www.surfaquarium.com/miinvent.html

Mckenzie, W. (2002). Gardner's Eight Criteria for Identifying Intelligence. Arlington Public School. Retrieved May 5, 2010, from http://www. surfaquarium.com/MI/Criteria.html

Nail, D. (2002). Multiple intelligence Test. Retrieved May 17, 2010, from http://www.NedProductions-Multipl_Intelligence_Test.html

Saricaoglu, A., \& Arikan, A. (2009). A study of multiple intelligences, foreign language success and some selected variables. Journal of Theory and Practice in Education, 5(2), 110-122.

Simin, Sh., Tavakoli, M. (2015). Assessing speaking ability in academic context: Focusing on a mixed methods approach. International Journal of Research Studies in Language Learning, 4(1), 71-81.

Sit, P. S. (2007). Lesson study as a means to help kindergarten teachers develop children's reading comprehension ability. Journal of Research on Elementary and Secondary Education, 18, 145-164.

Spearman, C. (1927). The abilities of man: Their nature and measurement. New York: Macmillan.

Ur, P. (1996). A course in language teaching: Practice and theory. Cambridge: Cambridge University Press. 
Saibani, B. \& Simin, S.

\section{Appendix I}

Oral Exam Evaluation Criteria

\begin{tabular}{|c|c|c|c|c|}
\hline \multicolumn{5}{|c|}{ Fluency of Speech } \\
\hline 1 & 2 & 3 & 4 & 5 \\
\hline Poor & Below average & Average & Above average & Excellent \\
\hline \multicolumn{5}{|c|}{ Grammar Use } \\
\hline 1 & 2 & 3 & 4 & 5 \\
\hline Poor & Below average & Average & Above average & Excellent \\
\hline \multicolumn{5}{|c|}{ Listening Comprehension } \\
\hline 1 & 2 & 3 & 4 & 5 \\
\hline Poor & Below average & Average & Above average & Excellent \\
\hline \multicolumn{5}{|c|}{ Pronunciation } \\
\hline 1 & 2 & 3 & 4 & 5 \\
\hline Poor & Below average & Average & Above average & Excellent \\
\hline \multicolumn{5}{|c|}{ Vocabulary Appropriateness and Complexity } \\
\hline 1 & 2 & 3 & 4 & 5 \\
\hline Poor & Below average & Average & Above average & Excellent \\
\hline
\end{tabular}


The relationship between multiple intelligences and speaking skill among intermediate EFL learners in Iran

\title{
Appendix II
}

\author{
Multiple Intelligences Test
}

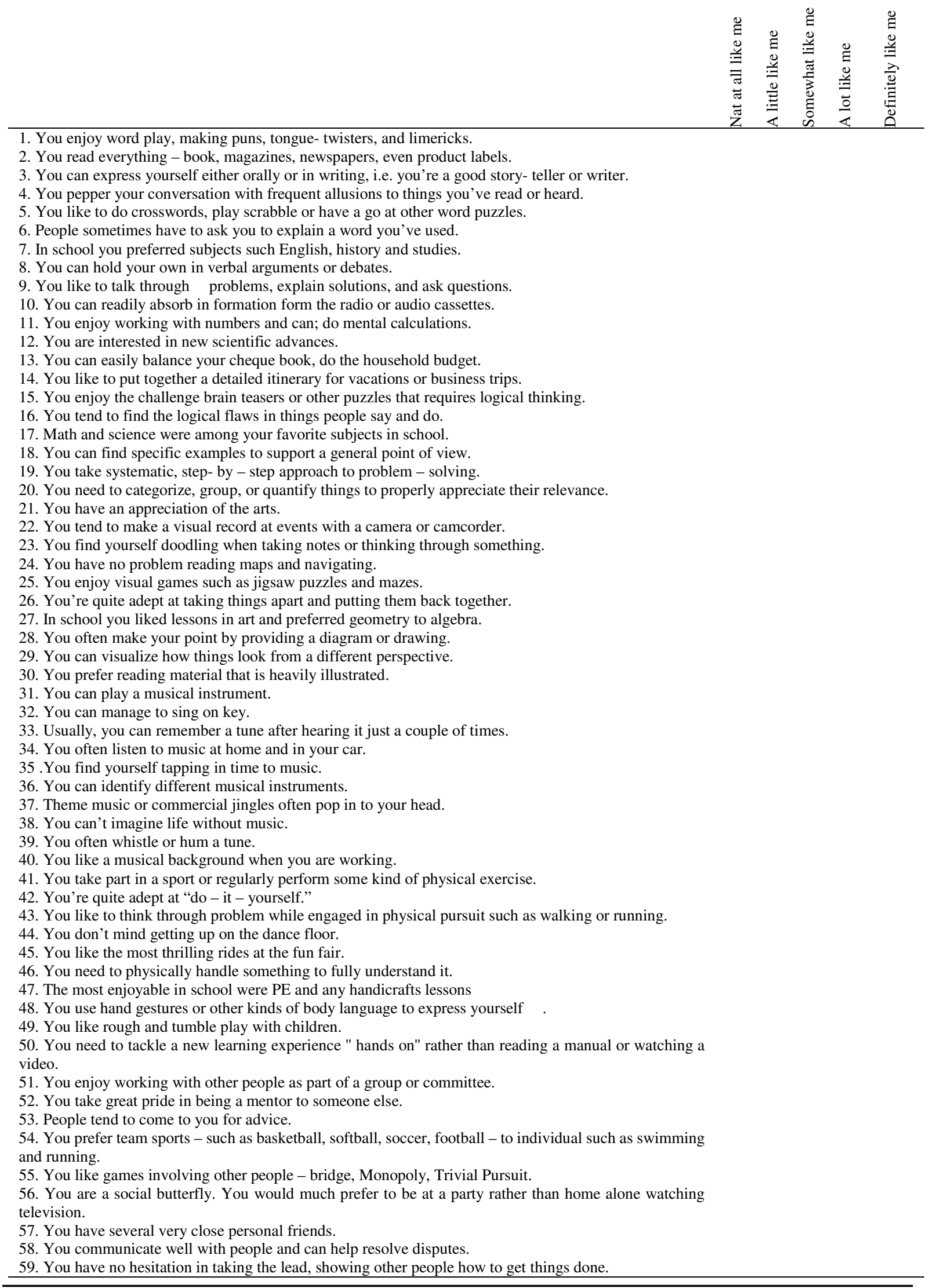


Saibani, B. \& Simin, S.

\footnotetext{
60. You talk over problems with others rather than trying to resolve them by yourself.

61. You keep a personal diary or log to record your innermost thoughts.

62. You have set your own goals - you know where you're going.

63. You often spend "quiet time" reflecting on the important issues in your life.

64. You are an independent thinker - you know your mind, make up your own mind.

65. You have a private hobby or internet which you don't really share with anyone else.

66. You like to go fishing by yourself or take a solitary hike. You re happy with your own company.

67. Your idea of a good vacation is an isolated hilltop cabin rather than a five - star resort and lots of people.

68. You have a realistic idea of your own strengths and weaknesses.

69. You have attended self - improvement workshops or been through some kind of counseling to learn more about yourself.

70. You work for yourself -or have seriously contemplated "doing your own thing".

71. You keep or like pets

72. You can recognize and name many different types of trees, flowers and plants.

73. You have an interest in and good knowledge of how the body works- where the main internal organs are, for example, and you keep abreast on health issues.

74. You are conscious of tracks, nests and wildlife while on a walk and can "read" weather signs.

75. You could envision yourself as a farmer or maybe you like to fish.

76. You are a keen gardener.

77. You have an understanding of, and interest in, the main global environmental issues.

78. You keep reasonably informed about developments in astronomy, the origins of the universe and the evolution of life.

79. You are interested in social issues, psychology and human motivations.

80. You consider that conservation of resources and achieving sustainable growth are two of the biggest issues of our times.

81. It is important to see my role in the "big picture" of things.

82. I enjoy discussing questions about life.

83. Religion is important to me.

84. I enjoy viewing art work

85. Relaxation and meditation exercises are rewarding to me.

86. I like traveling to visit inspiring places.

87. I enjoy reading philosophers.

88. Learning new thing is easier when I see their real world application.

89. I wonder if there are other forms of intelligent life in the universe.

90. It is important for me to feel connected to people ideas and beliefs.
} 